\title{
Regresi Linier Pada Forcasting Sistem Penunjang Keputusan Penentuan Jenis Penyakit Pada Hewan Ternak Unggas
}

\author{
Iwan Purwanto, Adrian Sjamsul Qomar \\ Prodi Sistem Informasi, Jurusan Teknik Informatika \\ Fakultas Teknologi Industri \\ Universitas Trisakti \\ Jakarta, Indonesia \\ iwan.purwanto@trisakti.ac.id, adrian.qamar@trisakti.ac.id
}

\begin{abstract}
Abstrak-Unggas merupakan salah satu makhluk hidup yang dapat dikonsumsi baik dagingnya ataupun telurnya oleh manusia. Jumlah terbayak dari jenis ungags yang dapat dikonsumsi oleh manusia adalah Ayam. Dari berbagai segi, peternakan unggas dalam hal ini adalah ayam, dapat dimanfaatkan segala komponennya diantaranya adalah dagingnya dapat dikonsumsi, telurnya pun dapat dikonsumsi, bahkan kotorannya, dapat dipergunakan sebagai pupuk kendang. Oleh karena itu semua bagian dapat dimanfaatkan sebagaimana mestinya. Indonesia sendiri membutuhkan jumlah daging dan telur ayam yang begitu besar setiap harinya. Hal tersebut karena masyarakat telah sadar akan nilai dan mafaat daging serta telur ayam bagi kesehatan. Namun demikian peternat tidak sedikit yang mengalami kerugian yang dikarenakan gagal panen, dimana gagal panen tersebut disebabkan oleh terserangnya penyakit. Banyak peternak yang belum memiliki kemampuan dalam mendeteksi kondisi penyakit yang diderita oleh uanggas sedini mungin menyebabkan para peternak merusi. Hal tersebut disebabkan oleh kurangnya pemahaman terhadap kondisi gejala yang cepat menyebar oleh unggas yang bukan tidak mungkin menyebabkan kematian masal. Hal tersebut akan menyebabkan peternak unggas merugi. Guna meminimalisir kerugian yang terjadi di atas, penelitian ini akan membahas sistem penunjang keputusan/decision support systems (DSS) penentuan jenis penyakit pada ungas dengan menggunakan pendekatan regresi linier. Dalam desain akan ditentukan kedekatan/kemiripan suatu kondisi pada kondisi tertentu yang menyerupai objek sebagai pengambil keputusannya.
\end{abstract}

Kata Kunci: Unggas, DSS, regresi linier, jenis penyakit, kedekatan/kemiripan

\section{Pendahuluan}

Pada masa pendemi seperti ini, kebutuhan akan asupan protein sangat dibutuhkan oleh masyarakat. Hal tersebut mengakibatkan meningkatnya jumlah kebutuhan unggas dalam hal ini adalah ayam potong guna pemenuhan kebutuhan di atas. Berdasarkan data yang terhimpun menunjukan bahwa dari 47 perusahaan pembibit ayam potong dapat mengestimasi tingkat sebaran pada angka 174.917.479 akor atau setara daging ayam sebanyak 205.178 ton[3]. Sementara kebutuhan daging ayam maret mencapai angka 214.760 .548 ekor. Artinya telah terdapat kekurangan di pasaran. Kekurangan tersebut disebabkan oleh terjadinya gagal panen yang disebabkan kematian ayam saat dalam

\section{Metodologi}

Penelitian ini menggunakan metode deskriftif dengan menggunakan pendekatan kualitatif. Metode yang digunakan dalam proses pengukuran nilai kedekatan adalah Regresi Linier dan dengan menggunakan konsep pendekatan sepagai penunjang keputusannya.

\section{A. Regresi Linier}

peternakan.Kondisi tersebut bukan kali pertama yang dialami oleh para peternak unggas[1].

Guna meminimalisir terjadinya kerugian yang disebabkan oleh kemarian hewan unggas, maka perlu dilakukan edukasi bagi para peternak guna mengantisipasi sedini mungkin melalui pemahaman gejala yang dialami oleh ayam saat mengalami kondisi tertentu. [6] Pada sisi lain, guna meminimalisir kejadian yang menyebabkan kerugian konsumen, dirancang suatu aplikasi yang bertujuan sebagai pendeteksi jenis penyakit pada unggas peliharaan khususnya ayam potong, sebagai pengambil keputusan jenis penyakit yang diidap oleh ayam tersebut[7].

Regresi linier merupakan suatu metode statistik yang berfungsi untuk melakukan pengujian sejauh mana hubungan sebab akibat dan kedekatan terhadap suatu unsur (x) terhadap variablel dampaknya. Dimana faktor dampak dilambangkan dengan $\mathrm{Y}$ atau sering dikenal dengan Respons, sementara faktor penyebab (X) biasanya dikenal dengan istilah Predictor. Regrasi Linier Sederhana 
sering disebut dengan SLR (Simple Linear Regression). Diman SLR juga merupakans alah satu metode statistik yang digunakan untuk melakukan peramalan atau prediksi suatu kualitas atau kuantitas. Melalui metode tersebut di atas, peneliti mengharapkan dapat ditemukannya hasil pemetaan dengan menggunakan beberapa kondisi pada specimen kedekatan atau sebaliknya pada penentuan Sisem Penunjang Keputusan.

Model persamaan Regresi Linier Sederhana dapat dideskripsikan pada suatu rumus seperti di bawah ini:

$\mathrm{Y}=\mathrm{a}+\mathrm{bX}$

Dimana:

$\mathrm{Y}=$ Variabel Response atau variable dampak (dependent)

$\mathrm{X}=$ Variabel Predictor atau variable fakyor penyebab (independent)

$\mathrm{a}=$ konstanta

$\mathrm{b}=$ koefisien regresi (kemiringan), besaran respons yang ditimbulkan opeh Predictor

Nilai a dan b dapat dikalkulasikan dengan menggunakan formula di bawah ini:

$$
\begin{aligned}
& =\frac{\left(\sum Y\right)\left(\sum X^{2}\right)-\left(\sum Y\right)\left(\sum X Y\right)}{n\left(\left(\sum X^{2}\right)-\left(\sum Y\right)^{2}\right.} \\
& b=\frac{n\left(\sum X Y\right)-\left(\sum x\right)\left(\sum Y\right)}{n\left(\left(\sum X^{2}\right)-\left(\sum Y\right)^{2}\right.}
\end{aligned}
$$

Demikian di bawah adalah tahapan dalam menentukan Analisa Regresi Linier Sederhana:

1. Tentukan tujuan melakukan Analisa Regresi Lineier Sederhana

2. Identifikasi variable factor penyebab (Predictor) dan Variabel Dampak (Response)

3. Lakukan pengumpulan data

4. Hitung X2, Y2, XY dari masinng-masing jumlah totalnya

5. Hitung a dan b berdasarkan rumus di atas

6. Desain model persamaan Regresi Linier Sederhana

7. Lakukan Prediksi atau peramalan terhadap variable factor atau variable dampak.

\section{B. Sistem Senunjang Keputusan/Decision Support} Systems (DSS)

\section{Hasil dan Pembahasan}

Sistem Penunjang Keputusan adalah suatu sistem informasi yang dalam proses penyimpulan keputusannya menggunakan beberapa indicator sebagai subjek pengambilan simpulan. Dengan menggunakan beberapa masukan tersebut, system akan melakukan penganalisaan bersarakna pengkondisian tertentu, mana keputusan yang akan diambil berdaasrkan suatu kondisi dengan menggunakan formula yang telah ditentukan. Pengkondisian tersebut mengerucut hingga menyimpulkan suatu informasi.

\section{A. Sumber Data}

Dalam penelitian ini, penulis melakukan penguulan data pada beberapa peternak ayam potong yang berada di kabupaten lampung selatan. Beberapa pendekatan yang
Sistem Penunjang keputusan yang sering dikenal dengan Decision Support Systems (DSS) merupakan bagian dari suatu sistem informasi berbasis komputer (termasuk dalam rumpun sistem informasi pengetahuan) yang dipergunakan sebagai pengambilan keputusan atas suatu kondisi.

DSS dapat juga dikondisikan sebagai system computer yang mengelola data menjadi informasi, atau inforasi level A ke informasi tingkat lanjutnya guna pengambilan suatu keputusan. SPK juga dapat dikatakan sebagai sistem yang memiliki kemampuan sebagai pendukung ad hock analyst berupa data dan informasi guna pengambilan suatu keputusan[2].

Decision Support System merupakan suatu system yang berbasis ilmu pengetahuan. Berdasarkan kinsep yang diterapkannya mengatakan bahwa, rancangan yang baik adalah system yang berbasis software terinteraksi yang ditujukan membantu pengambilan keputusan, berorientasi pada keputusan, berorientasi pada perencanaan tahapa selanjutnya, dan dapat dipergunakan pada kondisi-kondis tertentu.

Tujuan akhir dari pemanfaatana DSS adalahmemberikan pelayanan kepada pengguna terkait kemudahan pengambilan keputusan yang memiliki nilai ketepatan yang sangat tinggi. Penentuan nilai ketepatan tersebut dapat dikoordinasikan dengan menggunakan metode statistika yang disebutkan di atas[4].

Beberapa tahapan yang harus dilalui dalam aktifitas Sistem Penunjang Keputusan adalah sebagai berikut:

1. Pendefinisian suatu masalah berdasarkan gejala

2. Pengumpulan data dan informasi yang relefan

3. Mengolah data menjadi suatu informasi dengan menggunakan beberapa pendekatan

4. Menentukan alternatif atau solusi dari temuan yang merupakan hasil dari keputusan

Dalam melakukan pemprsesan SPK dapat menggunakan bantuan dari sistem lain, selain menggunakan Regresi Linier Sederhana, diantaranya adalah Artificial Intelligence, Expert Systems, Fuzzy Logic, dan lain sebagainya.

Pada dasarnya DSS juga telah mengadopdi beberapa unsur penyusunnya, salah satu diantaranya adalah: menggunakan hubungan beberapa indikator sebagai subjek pengambilan keputusannya[5].

dilakukan diambil berdasarkan pengkondisian subjek saat berjalan.

\section{B. Variabel yang digunakan}

Proses perhitungan yang dipergunakan dalam penelitian ini menggunakan konsepe Regresi Linier Sederhana, dimana factor penentu yang memperkuat perhitungan adalah sebagai berikut:

$\mathrm{Y}=$ Variabel Response atau variable dampak (dependent)

$\mathrm{X}=$ Variabel Predictor atau variable fakyor penyebab (independent)

$\mathrm{a}=$ konstanta

$\mathrm{b}=$ koefisien regresi (kemiringan), besaran respons yang ditimbulkan opeh Predictor 
Formulasi perhitungan dilakukan dengan menggunakan beberapa indikator yang disesuaikan dengan kondisi medan saat dilakukannya survei.

\section{Metode Analisa yang digunakan}

Proses Analisa data dilakukan berdasarkan pengkondisian flow yang ada di bawah ini:

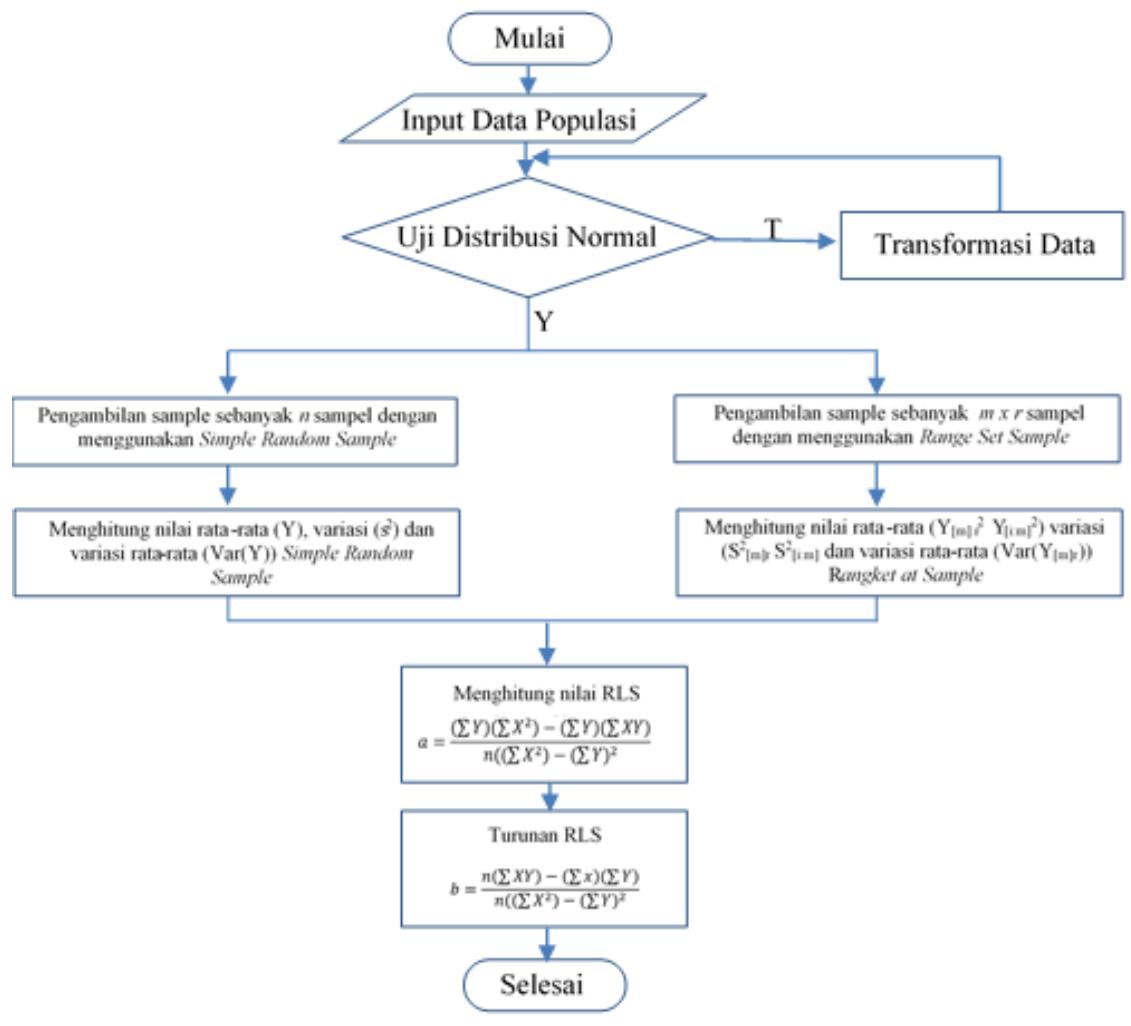

Gambar 1. Diagram Alir Ranked Set Sampling

\section{Pembahasan}

Berdasarkan akumulasi dari beberapa sebaran sampling dengan mengembangkan pengujian Sinpsinus-Agregate diperoleh nilai bahwa pada kondisi $\alpha=7 \%$ data masukan doc dan data prediksi panen tidak dapat diakumulasikan dengan tingkatan prediksi normal. Dengan demikian harus dilakukan turunan dari aktifitas di atas yaitu $\mathrm{Y}^{\prime}=\exp \left(\left(\log 10\right.\right.$ (produksi) dan $\mathrm{X}^{\prime}=\exp (\log 10$ (luas panen $\left.)\right)$. Berdasarkan hasil prngujian dengan reduksi normal dalamdata transformasi didapat bahwa $\alpha=7 \%$ data ekonstProduksi dan data e-konshasil_panen berjalan dengan cara normal. Menindak lanjuti pada Analisa korelasi peridentitas dapat disimpulkan bahwa dengan kondisi $\alpha=7 \%$ antara para e-konst Produksi dan data ekonshasil_panen terdapat korelasi. Berdasarkan Simple Rundown Sampling, didapatkan hasil akumulasi sebaran nilia Y', sebaran nilai X' dan sebaran nilai $\left(\beta_{-}(1(\mathrm{SRS}))^{\prime}\right)$ yang di gambarkan pada 1 di bawah ini:

Tabel 1 Nilai Sebaran ( $\left.Y^{\prime}\right)$

\begin{tabular}{llll}
\hline Ukuran Sampel $(n)$ & $n=25$ & $n=50$ & $n=75$ \\
Sebaran $(Y)$ & 467.025 & 315.172 & 186,4715
\end{tabular}

Dari table di atas dapat disimpulkan bahwa $n$, memiliki nilai sebaran $(Y)$ semakin kecil sehingga mengindikasikan bahwa Simple Rundown Sampling akan semakin baik.

Tabel 2 Model Regresi Linier Sederhana dan Nilai Sebaran Bersekala Dengan Menggunakan Regresi Linier Sederhana Simple Random Sampling

\begin{tabular}{|c|c|c|c|}
\hline Kons & Model Regresi & $\beta_{0(S R S)}$, & $\beta_{1(S R S)}$, \\
\hline$n=25$ & e-konshasil_panen $=-10.571+3.214$ e-konstProduksi & 2421.643 & 0.4254388 \\
\hline$n=50$ & e-konshasil_panen $=-10.062+3.009$ e-konstProduksi & 965.632 & 0.2434475 \\
\hline$n=75$ & e-konshasil_panen $=-11.279+3.086$ e-konstProduksi & 682.5488 & 0.0967443 \\
\hline
\end{tabular}


Berdasarkan tabel 2 di atas dapat disimpulkan bahwa berdasarkan peramalan nilai $n$, dengan regresi sebaran nilai $\left(\beta_{0(S R S)}\right)$ terhadap sebaran nilai $\left(\beta_{1(S R S)}{ }^{\prime}\right)$ menunjukan nilai pergeseran ke arah lebih kecil, hal tersebut mengindikasikan bahwa penilaian terhadap Simple Random Sampling semakin baik.

Berdasarkan Rangked Set Sampling, didapat nilai Sebaran $\left(Y_{[m] r}{ }^{\prime}\right)$ yang dapat dinarasikan pada tabel si bawah ini

Tabel 3 Nilai Sebaran $\left(Y_{[m] r^{\prime}}\right)$

\begin{tabular}{lllllll}
\hline & $m r=25$ & & $m r=50$ & $m r=75$ & \\
Formulasi & $m=5$ & $m=7$ & $m=5$ & $m=7$ & $m=5$ & $m$ \\
$\boldsymbol{Y}_{[\mathbf{m}] \mathbf{r}} \boldsymbol{y}$ & 231.567432 & 108.769435 & 85.665302 & 71.8674301 & 54.9540076 & 33.7640977 \\
\hline
\end{tabular}

Berdasarkan table 3 di atas, diketahui bahwa, nilai sebaran yang ditentukan berdasarkan indikator di atas, menunjukan bahwa siklus yang di kondisikan dengan menggunakan persamaan $\boldsymbol{Y}_{[m] \boldsymbol{r}}$, di atas menunjukan bahwa semakin kecil nilai sebaran menunjukan bahwa semakin mendekati nilai ketepatan pada Rangked Set Sampling.

Pengujian pada kondisi di atas berdasarkan table perhitungan (tabel 1, tabel 2, dan tabel 3) menggambarkan bahwa pengkondisian yang dipergunakan dengan menggunakan Simple Rundown Sampling dan Rangked Set Sampling memiliki kesamaan penilaian, dan kondisi tersebut menunjuka penguatan pada konsep pendekatan Sistem Penunjang keputusan.

\section{E. Penerapan Sistem Penunjang Keputusan}

Berdasarkan pembobotan pada tingkat kesesuaian pada metode RLS, maka peneliti dan dinas peternakan bekerjasama dalam menentukan beberapa kriteria yang terpisah berdasarkan beberapa indicator kedekatan. Berikut di bawah adalah variabel-variabel dalam menentukan pembobotan dalam proses pendiaknosaan.

Tabel 4 Bobot Indikator Gejala pada Ayam Potong dan Sub Indikator

\begin{tabular}{|c|c|c|c|}
\hline No & Indikator & Sub Indikator & Bobot \\
\hline \multirow[t]{6}{*}{1} & Mata & Merah & 0,5 \\
\hline & & Bengkak & 0,45 \\
\hline & & Berair & 0,4 \\
\hline & & Keputihan & 0,35 \\
\hline & & Pupil melebar & 0,3 \\
\hline & & Normal & 0,25 \\
\hline \multirow[t]{3}{*}{2} & Wajah & Terdapat benjolan & 0,5 \\
\hline & & Bintik-bintik & 0,45 \\
\hline & & Noral & 0,4 \\
\hline \multirow[t]{4}{*}{3} & Hidung & Berair & 0,5 \\
\hline & & Bengkak & 0,45 \\
\hline & & Bentol & 0,4 \\
\hline & & Normal & 0,35 \\
\hline \multirow[t]{4}{*}{4} & Mulut/Paruh & Berair & 0,5 \\
\hline & & Bengkak & 0,45 \\
\hline & & Bentol & 0,4 \\
\hline & & Normal & 0,35 \\
\hline \multirow[t]{4}{*}{5} & Bulu & Basah/lembab/berkeringat & 0,5 \\
\hline & & Rontok & 0,45 \\
\hline & & Kusam & 0,4 \\
\hline & & Normal & 0,35 \\
\hline \multirow[t]{4}{*}{6} & Lutut dan Kaki & Bengkok & 0,5 \\
\hline & & Bentol & 0,45 \\
\hline & & Lumpuh & 0,4 \\
\hline & & Normal & 0,35 \\
\hline \multirow[t]{4}{*}{7} & Pernafasan & Sesak & 0,5 \\
\hline & & Terengah-engah & 0,45 \\
\hline & & Tergesah-gesah & 0,4 \\
\hline & & Normal & 0,35 \\
\hline \multirow[t]{5}{*}{8} & Dubur/Anus & Bengkak & 0,5 \\
\hline & & Benjol & 0,45 \\
\hline & & Kotor & 0,4 \\
\hline & & Berair & 0,35 \\
\hline & & Kotor berwarna darah & 0,3 \\
\hline
\end{tabular}




\begin{tabular}{|c|c|c|c|}
\hline & & $\begin{array}{l}\text { Kotor kering berwarna } \\
\text { putih }\end{array}$ & $\begin{array}{l}0,25 \\
0,2\end{array}$ \\
\hline & & Normal & \\
\hline \multirow[t]{4}{*}{9} & Tinja/Fases & Kehijauan & 0,5 \\
\hline & & Putih seperti kapur & 0,45 \\
\hline & & Cair & 0,4 \\
\hline & & Normal & 0,35 \\
\hline \multirow[t]{4}{*}{10} & Pertumbuhan & Badan & 0,5 \\
\hline & & gemuk/obesitas & 0,45 \\
\hline & & Badan terlalu kurus & 0,4 \\
\hline & & Normal & \\
\hline \multirow[t]{4}{*}{11} & Nafsu Makan & Banyak makan & 0,5 \\
\hline & & Menurun & 0,45 \\
\hline & & Tidak mau makan & 0,4 \\
\hline & & Normal & 0,35 \\
\hline \multirow[t]{4}{*}{12} & Nafsu Minum & Banyak minum & 0,5 \\
\hline & & Menurun & 0,45 \\
\hline & & Tidak mau minum & 0,4 \\
\hline & & Normal & 0,35 \\
\hline \multirow[t]{3}{*}{13} & Suara & Mencicit & 0,5 \\
\hline & & Ngorok & 0,45 \\
\hline & & Normal & 0,4 \\
\hline \multirow[t]{5}{*}{14} & Pergerakan & Lemah & 0,5 \\
\hline & & Kehilangan keseimbangan & 0,45 \\
\hline & & Pincang & 0,4 \\
\hline & & Tidak dapat berdiri & 0,35 \\
\hline & & Normal & 0,3 \\
\hline \multirow[t]{5}{*}{15} & Keadaan & Kematian mendadak & 0,5 \\
\hline & & Kejang-kejang & 0,45 \\
\hline & & Menggigil & 0,4 \\
\hline & & Tidak terlihat normal & 0,35 \\
\hline & & Normal & 0,3 \\
\hline \multirow[t]{4}{*}{16} & Kepala & Bengkak & 0,5 \\
\hline & & Benjol & 0,45 \\
\hline & & Berputar terbalik & 0,4 \\
\hline & & Normal & 0,35 \\
\hline
\end{tabular}

Berdasarkan penentuan tabel di atas dengan dikolaborasikan proses perhitungan sebaran varian Simple Random Sampling dan Rangked Set Sampling pada RLS adalah sebagai berikut:

Tabel 5 Sebaran Ver 1

\begin{tabular}{llll}
\hline & \multicolumn{2}{c}{ Nilai Sebaran SRS } & \multicolumn{1}{l}{ RSS } \\
No & $\boldsymbol{\beta}_{\mathbf{0}(\boldsymbol{S} \boldsymbol{R} \boldsymbol{S})}$ & \multicolumn{1}{c}{$\boldsymbol{\beta}_{\mathbf{1}(\boldsymbol{S} \boldsymbol{R} \boldsymbol{S})}$} & $Y_{[m] r}$ \\
\hline$n=1$ & 21.56437 & 18.63582 & 9.38635 \\
$n=2$ & 22.35479 & 17.36659 & 8.37348 \\
$n=3$ & 23.54386 & 18.30769 & 11.13213 \\
$n=4$ & 20.56839 & 16.50765 & 13.35721 \\
$n=5$ & 18.56243 & 12.82768 & 9.34235 \\
$n=6$ & 16.86439 & 11.709266 & 9.13434 \\
$n=7$ & 20.60564 & 15.82650 & 12.34131 \\
$n=8$ & 23.65408 & 21.80955 & 19.34263 \\
$n=9$ & 18.36549 & 16.7258 & 10.45341 \\
$n=10$ & 27.80753 & 11.70652 & 6.352245 \\
$n=11$ & 16.56289 & 9.66005 & 8.524234 \\
$n=12$ & 19.50895 & 12.72544 & 9.67433 \\
$n=13$ & 20.67543 & 11.72964 & 8.3434345 \\
$n=14$ & 22.75306 & 9.368898 & 7.453435 \\
$n=15$ & 22.83076 & 12.625409 & 11.34534 \\
$n=16$ & 21,78355 & 18.264711 & 13.347778 \\
\hline
\end{tabular}


Berdasarkan nilai di atas perhitungan terhadap kedekatan nilai dna kesesuaian dalam penentuan sistem penunjang keputusan, terdapat gambaran dalam proses pemetaan pada table 5 di atas yang menunjukan tingkat konsistensi kesesuatain dan kedekatan berdasarkan beberapa indicator. Hal tersebut menunjukan bahwa tingginya tikngkat konsistensi, menunjukan bahwa baiknya penggunaan system dalam proses pengambilan keputusan yang didukung dengan sistem RLS.

\section{Kesimpulan}

Tingginya tingkat konsistensi yang dihasilkan berdasarkan Regresi Linier Sederhana, dalam konsep Sistem Penunjang keputusan yang diaplikasikan pada hewan ternak unggas berdasarkan penelitian ini adalah sebagai berikut:

a. Berdasarkan pengambilan sampel pada nilai ukur ( $\mathrm{n}=$ $\mathrm{mr})$ 25, 50, 75 dengan menggunakan yang tertera menunjukan bahwa nilai RP' $>1$ dan RS' $>0$, sehingga Rangked Set Sampling lebih baik dari pada Simple Random Sampling walaupun keduanya memiliki banyak kemiripan dalam proses penentuan nilai akhir.

b. Nilai Y[m]r' menurun pada set-size (m) namun pada $\mathrm{mr}$ tetap. Hal ini menunjukan semakin besarnya nilai $\mathrm{m}$ dan semakin sedikitnya nilai $\mathrm{r}$, akan menunjukan bahwa Rangked Set Sampling akan semakin baik.

c. Tingginya tingkat konsistensi dalam penilaian yang di lakukan berdasarkan beberapa pendekatan menunjukan bahwa tingkat kerentanan yang terjadi pada penilaian sangat baik

d. Penilaian yang menunjukan semakin kecilnya nilai dengan kondisi penentuan nilai awal yang semakin besar menunjukan bahwasanya metode yang dipergunakan menunjukan kearah yang cenderung membaik.

e. Kepekatan dalam proses sinkronisasi perhitungan menggambarkan bahwa hubungan anatara metode dan desain system saling mendukung dan memperngaruhi.

\section{Daftar Pustaka}

[1] Atmomarsono., Suprijatna, E.D, Sunarti. U., dan W. Sarengan "Kesiapan bahan pakan dalam Mendukung pengembangan Unggas Lokal". Prosiding Workshop Nasional Unggas Lokal Pusat penelitian dan Pengambangan Peternakan. Badan penelitian dan Pengambangan Pertanian, kemenetrian pertanian, Jakarta. 2012

[2] Boyaci, A and Calish, A., "Data Mining application in Banking Sectors with Clustering and Classification Method". International Conference on Insdustrial Engineering and Operations Management Dubai: IEEE Conference Publications. 2015.

[3] Direktorat Jenderal Peternakan "Populasi Ternak unggas Lokal, dan produksi Danging dan telur". Direktorat Jenderal Peternakan dan Kesehatan hewan kementerian pertanian, Jakarta. www.pertanian.go.id/ap_pages/mad/datanak 2018.

[4] Faqih, H., "implementasi Dengan Metode SAW Untuk Menentuka Pripritas Operasi dan Pemeliharaan Sistem Irigasi DPU Kabupaten tegal" Bianglala Informatika. Vol II., No. 12014.

[5] Suryanto, "Data Mining Untuk Klasifikasi dan Klasterisasi Data", informatika Bandung. 2017,

[6] Sumardi I.K. dan Dewi, S.A.M.K., I.G "Pengaruh Kandungan Energi dan Protein ransum Terhadap penampilan Ayam kampung Usia 10-20 Minggu”. Proseiding seminar Nasional Peternakan Berkelanjutan 4: Inovasi Agribisnis Peternakan untuk Ketahanan pangan. ISBN: 978-602-9808-6-2-p:155160. 2012.

[7] Yuwono, D.M. dan F.R. Prasetyo Analisis dan Teknis Ekonomi Agribisnis Ayam Buras Sistem Semi Intensif (Studi Kasus di KUB Ayam kampung Unggul Desa Krengseng. Kecamatan Gringsing, Kabupaten batang). Prosiding Seminar Nasional: menggagas Kebangkita Komuditas Unggul Lokal Pertanian dan Kelautan Fakultas Pertanian, Universitas Turnojoyo Madura, juni. :17-24. 2013 